Int. J. Dev. Biol. 61: 621-632 (2017)

doi: $10.1387 / \mathrm{ijdb} .170121$ to

\title{
Metamerism in cephalochordates and the problem of the vertebrate head
}

\author{
TAKAYUKI ONAI ${ }^{* 1,2}$, NORITAKA ADACHI ${ }^{1}$ and SHIGERU KURATANI ${ }^{1}$ \\ 'Evolutionary Morphology Laboratory, RIKEN center for Developmental Biology, Chuo-ku, Kobe, Japan and \\ ${ }^{2}$ Department of Anatomy, School of Medical Sciences, University of Fukui, Matsuokashimoaizuki, Japan
}

\begin{abstract}
The vertebrate head characteristically exhibits a complex pattern with sense organs, brain, paired eyes and jaw muscles, and the brain case is not found in other chordates. How the extant vertebrate head has evolved remains enigmatic. Historically, there have been two conflicting views on the origin of the vertebrate head, segmental and non-segmental views. According to the segmentalists, the vertebrate head is organized as a metameric structure composed of segments equivalent to those in the trunk; a metamere in the vertebrate head was assumed to consist of a somite, a branchial arch and a set of cranial nerves, considering that the head evolved from rostral segments of amphioxus-like ancestral vertebrates. Non-segmentalists, however, considered that the vertebrate head was not segmental. In that case, the ancestral state of the vertebrate head may be non-segmented, and rostral segments in amphioxus might have been secondarily gained, or extant vertebrates might have evolved through radical modifications of amphioxus-like ancestral vertebrate head. Comparative studies of mesodermal development in amphioxus and vertebrate gastrula embryos have revealed that mesodermal gene expressions become segregated into two domains anteroposteriorly to specify the head mesoderm and trunk mesoderm only in vertebrates; in this segregation, key genes such as delta and hairy, involved in segment formation, are expressed in the trunk mesoderm, but not in the head mesoderm, strongly suggesting that the head mesoderm of extant vertebrates is not segmented. Taken together, the above finding possibly adds a new insight into the origin of the vertebrate head; the vertebrate head mesoderm would have evolved through an anteroposterior polarization of the paraxial mesoderm if the ancestral vertebrate had been amphioxus-like.
\end{abstract}

KEY WORDS: amphioxus, metamerism, vertebrate head, mesoderm, somite, evolution

\section{Introduction}

The evolution of the vertebrate head has been a fundamental issue in biology and highly controversial for more than two hundred years (Goethe, 1790, Oken, 1807, Ahlborn, 1884, Goodrich, 1930, Romer, 1972, Gee, 1996, Kuratani, 1997, Kuratani, 2003, Kuratani, 2008, Conway Morris and Caron, 2014). For addressing the issue, the cephalochordate (the amphioxus), belonging to the phylum Chordata (Chephalochordata, Urochordata, Vertebrata), has been one of the key animals for its phylogenetic position as the most basal living chordate, and sharing basic chordate structures such as the dorsal nerve cord, notochord, somites and pharynx (MacBride, 1897, Van Wijhe, 1902, Goodrich, 1930, Holland et al., 2008a, Onai et al., 2014). In addition to the morphological similari- ties, the genomic study on the amphioxus revealed that the genome has evolved very slowly, sharing many conserved genomic regions with vertebrates, and that the amphioxus has never experienced the two rounds of whole genome duplication (a potential key event for vertebrate evolution) (Putnam et al., 2008, Holland and Onai, 2011). In contrast, Urochordata, the sister group of vertebrates, has undergone rapid evolution and lost many developmental genes and somites (Onai et al., 2010, Holland, 2016). The developmental mode of tunicates is mosaic, in which cell fate is determined as early as cleavage stages, making it difficult to compare with other chordate development (Holland, 2016). Given these facts, among

Abbreviations used in this paper: agd, anterior gut diverticulum; cg, club-shaped gland; m, mouth; es, endostyle; gs, gll slit; pp, preoral pit.

*Address correspondence to: Takayuki Onai. Department of Anatomy, School of Medical Sciences, University of Fukui, 23-3, Matsuokashimoaizuki, eiheiji-cho, Yoshida-
gun, Fukui 910-1193, Japan.Tel: 0776-61-8302. Fax: 0776-61-8132. E-mail: tonai @u-fukui.ac.jp -Web: http://ov-project.com - (iD http://orcid.org/0000-0002-5402-3828

Submitted: 29 May, 2017; Accepted: 11 July, 2017.

ISSN: Online 1696-3547, Print 0214-6282

(C) 2017 UPV/EHU Press

Printed in Spain 
extant invertebrate chordates, the amphioxus seems to be the best proxy to address the origin of the vertebrate body plan.

\section{History of studies of the vertebrate head problem}

Studies on the evolution of the vertebrate body plan, especially that of the head, has a long history and many problems. Therefore, it would be very informative to briefly summarize how synthesis has developed to recognize our current standing positions.

The pursuit of vertebrate body plan initiated in the 18th century when Goethe and Oken proposed 'The vertebral theory' (Goethe, 1790, Oken, 1807). In this theory, the vertebrate skull was considered as a composition of several vertebrae and the body plan of head was the same as that of trunk. The theory had a great impact on a number of researchers and they followed this primitive segmental view (Owen, 1854, see below), even after the Croonian Lecture by Huxley (Huxley, 1858).

In the late 19th century, with Charles Darwin's concept of evolution, anatomists and embryologists began to study the vertebrate head by using shark and skate, which were assumed to show the basic body plan of vertebrate. For instance, Gegenbaur classified cranial muscles, skeletons, and nerves of shark into segmental units of the head (Gegenbaur, 1871, Gegenbaur, 1872, Gegenbaur, 1887). Following this study, Balfour discovered three pairs of epithelial coeloms called head cavities (premandibular, mandibular, hyoid) in the shark and skate head mesoderm (Balfour, 1878). Van Wijhe scrutinized shark head cavities and cranial nerves, and redefined head segmentation; he separated somatic (a system for locomotion in the dorsal side) and visceral (a system for digestion in the ventral side) components in the head mesoderm, and identified head cavities as paraxial components of the mesoderm, but classified the pharyngeal arch mesoderm as visceral components (Van Wijhe, 1882). Before and after the discovery of head cavities in elasmobranch embryos, mesodermal segments were also observed in other vertebrates, such as amphibians and lampreys (Götte, 1875, Koltzoff, 1902, Goodrich, 1930), indicating an ancestral nature of head segments with vertebrates. Also Mitsukuri examined turtle embryos, and proposed that the head mesoderm of turtle embryos was comparable to rostral somites in amphioxus (Mitsukuri, 1893).

In the 20th century, new authors joined the debate and proposed their models with new data (Kuratani and Adachi, 2016). Among them, Goodrich stressed the consistency of segmental unit including somatic and visceral components of both mesoderm and nerve in the vertebrate body, and claimed eight segments in an archetypal vertebrate head that evolved from an amphioxus-like animal. His model was so influential that many scientists followed and to some extent were biased (Goodrich, 1918, de Beer, 1922, Goodrich, 1930, Neal and Rand, 1936, de Beer, 1947, Gilbert, 1952, Jollie, 1962, Jarvik, 1980). Of course, non-segmentalists existed and highlighted differences between head and trunk (Kingsbury and Adelman 1924; Kingsbury 1926), the above segmentalists'view has been prevalent and ascendant. For example, by using scanning electro microscopy (SEM) technology, Meier revealed mesodermal segments called somitomeres in chick and mouse embryonic heads (Meier, 1979, Meier and Tam, 1982, Jacobson, 1988). However, somitomeres were not clearly segmented like trunk somites, and no molecular studies have favored the presence of somitomeres so far. In lampreys, contrary to the previous study by Koltzoff, the SEM study showed that there were no somitomere-like mesodermal segments in the head mesoderm (Kuratani et al., 1999). Given that lampreys do not have any mesodermal segments in the head, and head cavities found in some gnathostomes might be a synapomorphy of jawed vertebrates, and rostral somites in the amphioxus might have evolved independently from head cavities. Conflicting to this idea, molecular studies on amphioxus embryos showed that rostral somites in amphioxus express some genes homologous to those expressed in the vertebrate head mesoderm (e.g. engrailed). With this evidence, Holland et al., have proposed homology - historically shared traits - between the amphioxus rostral somites and the vertebrate head mesoderm (Holland et al., 1997). In another paper, however, they found that amphioxus rostral somites shared homologous gene expression domains (e.g. pax3/7, delta) to that of the vertebrate trunk somites; amphioxus rostral somites have both vertebrate head and trunk mesodermal identities, and one to one relationship between amphioxus somites and vertebrate head mesoderm or trunk somites cannot be possible (Holland et al., 1999, Beaster-Jones et al., 2008).

As reviewed above, the controversy of vertebrate head segmentation is long-standing, highly tangled, and mainly focusing on the vertebrate side. What is lacking is the understanding of amphioxus body plan, which is essential for the comparison with vertebrates. In the amphioxus, two conspicuous segmental units, somites and gill slits, constitute the body. So, in the following sections, we review accumulated knowledge on metamerism in the amphioxus body and discuss the vertebrate head evolution from the point of view of invertebrate side.

\section{The amphioxus metamerism; ancestral or specialized?}

To regard the amphioxus as a proxy of an ancestral vertebrate, some peculiar features are problematic. In the amphioxus, initial formation of gill slits is very asymmetrical; about twelve primary gill slits develop in the right side of the pharynx (Willey, 1891). During metamorphosis, secondary gill slits arise next to the primary gill slits, and these gill slits are gradually arranged symmetrically along with the left/right (L/R) body axis (Willey, 1891). Since developmental sequences of gill slits are very peculiar, branchiomerism of the amphioxus was once thought as a specialized character, and nothing to do with ancestral traits in chordates (Romer, 1972). On the other hand, gill slits are a common trait shared in deuterostomes; a genomic organization of pharyngeal formation genes is well conserved in hemichordates, the amphioxus and vertebrates (Simakov et al., 2015); it is not likely that the amphioxus branchimerism is totally specialized.

On the anteroposterior arrangements of segments, the amphioxus larva has been assumed to experience a phase that somitomerism and branchiomerism correspond each other (Goldschmid, 1905, Kuratani, 1997, Kuratani, 2003, Yasui et al., 2014); reminiscent of the Goodrich's hypothetical ancestral vertebrates. Furthermore, these larvae named 'Amphioxides' developed gonads before metamorphosis (Goldschmid, 1905), suggesting that somitomerism and branchiomerism depended each other, constituting a single metameric system in ancestral chordates. On the other hand in extant vertebrates, relative positions, as well as developmental sequences of somites and gill slits along with the anterior/posterior $(A / P)$ body axis are very different. If head cavities are not counted as somatic segments, somitomerism and 
A
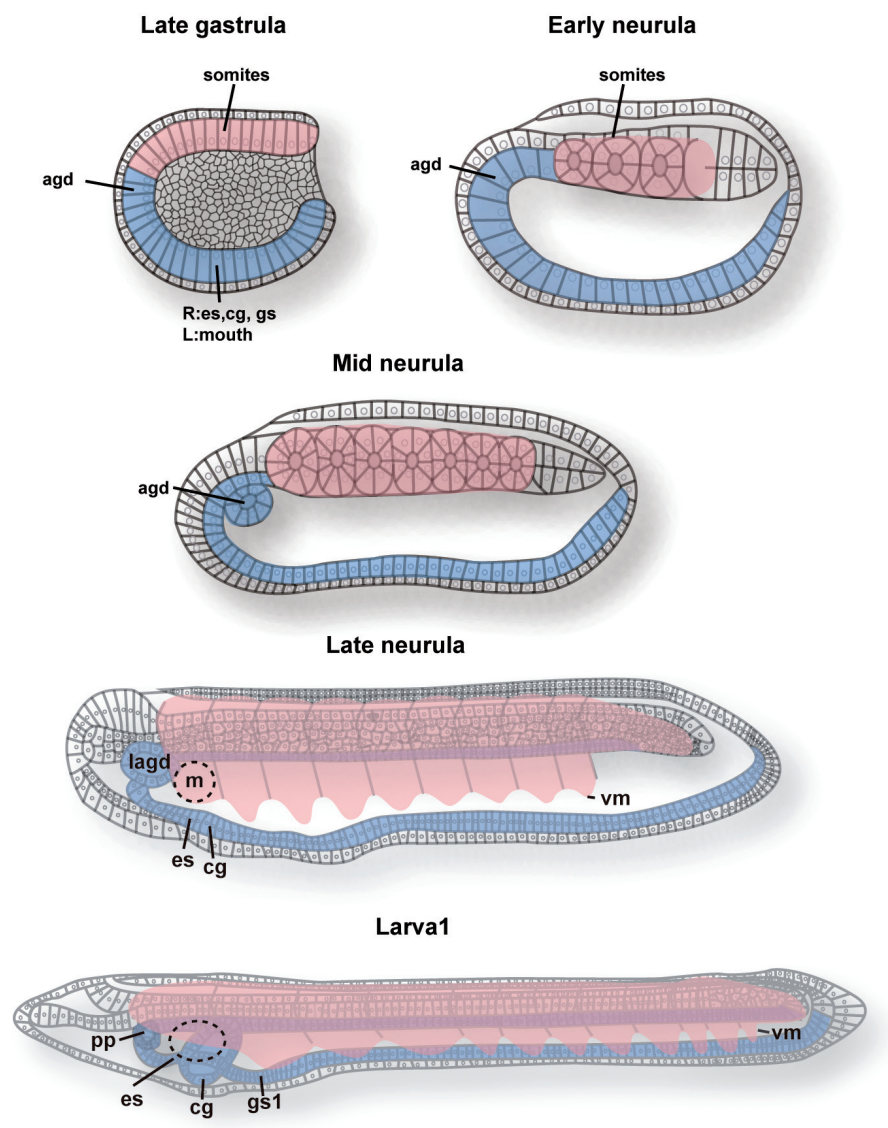

Larva2

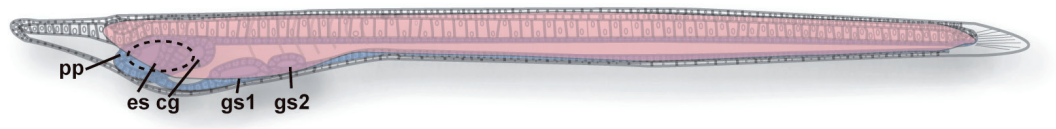

B

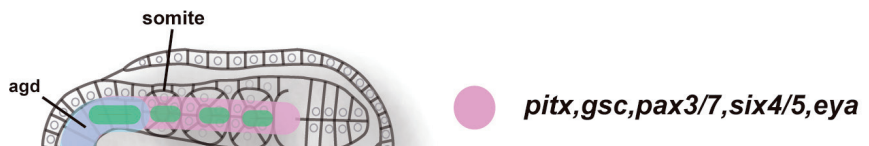

hex,otx,pax1/9,six4/5,eya

delta,hairyD,en,six $1 / 2$
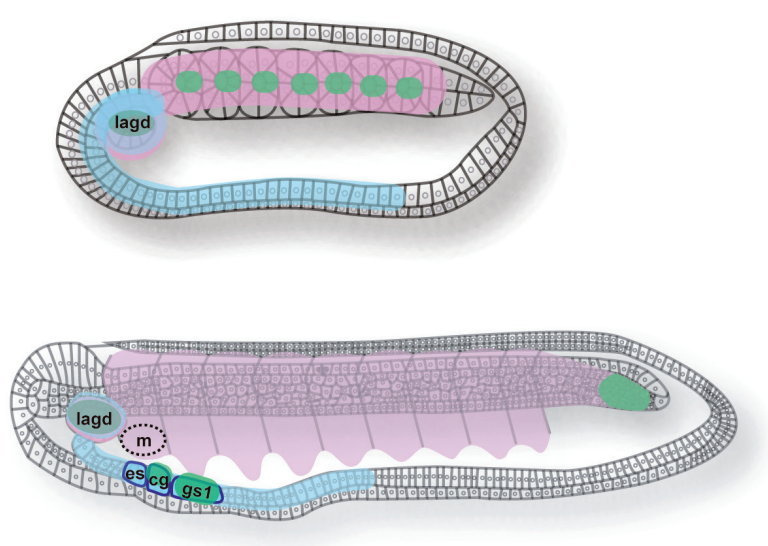

branchiomerism are largely independent in extant vertebrates (Ahlborn, 1884, Dean, 1899, de Beer, 1922, Damas, 1944, Kuratani, 2003). Therefore, in the vertebrate head/trunk evolution, a caudal shift of somitomerism and a rostral shift of branchiomerism might have occurred if ancestral vertebrates had been amphioxus-like (Kuratani, 1997).

\section{Somatic/visceral systems in the context of the vertebrate head problem}

Somitomerism arises in a somatic system while branchiomerism develops in a visceral system (Van Wijhe, 1882, Ahlborn, 1884, McMurrich, 1912, Kuratani, 2003); McMurrich, as well as Van Wijhe, considered the vertebrate body could be organized dualistically - somatic, visceral, which was pushed strongly later by Romer. According to Romer, some chordates have been very active for the presence of the somatic part of the body, which makes chordates contrast with other deuterostomes including the ambulacraria (echinodermata and hemichordata) (Romer, 1972). However, a current context does not support

Fig. 1. Development of somitomerism and branchiomerism in the amphioxus. (A) Development of somitomerism and branchiomerism in the amphioxus. The hypoblast differentiates into the dorsal mesoderm (pink) and the endoderm (light blue). From the dorsal mesoderm, metameric structure (Somites) forms. In the endoderm, agd (anteriorgut diverticulum) arises in the rostral tip. From the mid neurula to larva, the endostyle and club-shaped gland develop in the right side under the 1st somite whereas the 1st gill slit appears under the 2 nd somite. The mouth arises left side including the 1st somite. The preoral pit is derived from the left side agd that is located just rostral to the mouth. Agd; anterior gut diverticulum, es; endostyle, cg; club shaped grand, pp; preoral pit. Schemes were drawn by referring to Hatschek (1881). (B) Genetic maps for somitomerism and branchiomerism in the amphioxus. In the amphioxus, three major genetic groups are keys for somatic and visceral organogenesis. Pink is the group for somitomerism. Light blue is for branchiomerism. Green is for segmental border generation between segments. At the early neurula, genetic components for somitomerism (pink) and branchiomerism (light blue) are partially overlapped in the rostral hypoblast where the agd will differentiate. Genetic components in somitomerism and branchiomerism share the effectorgenes (pax, six, eya) those are considered as important for cell shape formation (Kozmik et al., 2007). Segmental genes (green) are expressed in the boundarybetween somites and posterior end of agd. At the mid neurula stage, the agd is divided into two (left and right). The left agd will differentiate into the preoral pit that expresses members of the three (pink, light blue, green) genetic components. At the late neurula stage, morphologically visceral organs (endostyle, club-shaped gland, gill slits, mouth) become clear. Some segmental genes are expressed in the tail bud but en is not expressed (green). Also in the lagd, cg, gs1, segmental genes such as delta are expressed (green). Agd; anterior gut diverticulum, lagd; left anterior gut diverticulum, m; mouth, es; endostyle, cg; club-shaped gland, gs 1; gill slit 1. 
this progressive evolution; a basal metazoan ctenophore swims actively in the ocean (Ryan et al., 2013); suggesting that somatic and visceral systems were present far before bilaterian evolution. When Romer claimed the theory, tunicates-a sessile organism on the ocean floor, but not the amphioxus - a free swimmer, was thought as the most basal living chordate, but now their positions are replaced each other in the tree, putting the amphioxus to the position of the most basal living chordate. Therefore, Romer's scenario of chordate evolution is now out of date. It is important to consider the head problem with a focus on both the somatic and visceral systems; both somatic elements (e.g. eye muscles, sense organs, brain) and visceral ones (e.g. branchial bars, muscles and nerves) compose the vertebrate head, which is regarded as a united complex of somatic/visceral elements. In this review, to consider how the vertebrate head evolved from invertebrate chordate ancestors, we first summarize morphology and development of segments in somatic and visceral systems of the amphioxus with current progress in molecular studies. Next, we deal with the evolution of somatic and visceral systems in chordates, and how the two systems correlate with the origin of the vertebrate head.

\section{Somitomerism; development of somites in the amphioxus}

We will summarize current understanding of the amphioxus somite formation in morphology and genetic mechanisms. Dur-

TABLE 1

\section{KEY GENES FOR SOMITOMERISM}

\begin{tabular}{|c|c|c|c|c|c|c|}
\hline \multicolumn{7}{|l|}{ Somites } \\
\hline Gene name & Late gastrula & Early neurula & Mid neurula & Late neurula & Early larva & Refs \\
\hline notch & 0 & 0 & 0 & 0 & 0 & Holland(2001) \\
\hline delta & $\mathrm{O}$ & 0 & 0 & 0 & 0 & Rasmussen(2007) \\
\hline hairyD & 0 & 0 & 0 & 0 & 0 & Mingullion(2003) \\
\hline fgf8/17/18 & $\mathrm{O}$ & $x$ & $x$ & $x$ & $x$ & bertrand(2011) \\
\hline wnt3 & 0 & 0 & 0 & 0 & 0 & schubert(2001) \\
\hline wnt5 & 0 & 0 & 0 & 0 & 0 & schubert(2001) \\
\hline wnt8 & 0 & $\mathrm{O}$ & 0 & $x$ & $x$ & schubert(2000) \\
\hline pitx & 0 & 0 & 0 & $x$ & $x$ & Yasui(2000) \\
\hline$t b \times 1 / 10$ & $x$ & - & O & 0 & $x$ & Mahadevan(2004) \\
\hline рах3/7 & 0 & 0 & $\mathrm{O}$ & $x$ & $x$ & Holland(1999) \\
\hline hox1 & $\mathrm{O}$ & 0 & $\mathrm{O}$ & 0 & $\mathrm{O}$ & Holland(2008) \\
\hline en & $x$ & 0 & $\mathrm{O}$ & $x$ & $x$ & Holland(1997) \\
\hline $\operatorname{six} 1 / 2$ & $\mathrm{O}$ & 0 & $\mathrm{O}$ & 0 & $x$ & Kozmik(2007) \\
\hline six $4 / 5$ & 0 & 0 & $\mathrm{O}$ & 0 & 0 & Kozmik(2007) \\
\hline eya & $\mathrm{O}$ & $\mathrm{O}$ & 0 & $\mathrm{O}$ & 0 & Kozmik(2007) \\
\hline muscle-actin & $x$ & 0 & 0 & 0 & 0 & Kusakabe(1997) \\
\hline \multicolumn{7}{|c|}{ Ventral mesoderm } \\
\hline vent1/2 & & & $\mathrm{O}$ & 0 & - & Kozmik(2001) \\
\hline twist & & & 0 & 0 & 0 & Meulemans(2007) \\
\hline ets & & & 0 & 0 & - & Meulemans(2007) \\
\hline$a l x$ & & & 0 & 0 & 0 & Meulemans(2007) \\
\hline bapx & & & $x$ & 0 & - & Meulemans(2007) \\
\hline cola & & & $x$ & 0 & 0 & Meulemans(2007) \\
\hline$t b \times 1 / 10$ & & & 0 & 0 & $\mathrm{O}$ & Mahadevan(2004) \\
\hline hand & & & 0 & 0 & 0 & Onimaru(2011) \\
\hline muscle-actin & & & $x$ & $x$ & $\mathrm{O}$ & Kusakabe(1997) \\
\hline
\end{tabular}

ing early embryogenesis of the amphioxus, mesoblastic somites arise from the paraxial mesoderm located in the dorsal mesoderm (Hatschek, 1881). The dorsal mesoderm is regionalized along with the $A / P$, dorsal/ventral (D/V) and medial/lateral (M/L) body axes during the gastrula stages (Holland and Onai, 2011). By the late gastrula stage, the dorsal side consists of the two layers (the epiblast and hypoblast) and begins to flatten (Fig. 1A) (Hatschek, 1893). At the neurula stage, chordate basic organs such as somites, the neural tube and notochord form (Fig. 1A) (Hatschek, 1881). The period of neurula can be divided into two phases; firstly somites and the neural tube develop; after that the notochord formation occurs (Hatschek, 1881). In the first phase, two lateral longitudinal folds of presumptive somites arise in the dorsal mesoderm by the time the neural canal becomes visible (Hatschek, 1881). Each rostral somite will contain a small cavity after the boundary between somites becomes sharp (Fig. 1A) (Hatschek, 1881). This cavity originally arises as a diverticulum of the archenteron (Hatschek, 1881). The rostral somites pinch off from the dorsal roof of the archenteron and this process is defined as enterocoely that is generally shared in deuterostomes but not in protostomes (Adoutte et al., 1999). The rostral somites eventually accentuate its outline and segregate each other. The rostral somites (8-14 dependent on species) pinch off from the archenteron, while more caudal somites bud off from the tail bud directly (Hatschek, 1881, Holland et al., 1997).

Recent molecular studies on development of the amphioxus embryos have revealed many genes expressed during somite formation in the dorsal mesoderm (Table1) (Beaster-Jones et al., 2008). During the early to mid gastrula stages, the hypoblast is regionalized into the dorsal mesoderm and endoderm ventrally along with the D/V axis (Holland and Onai, 2011). In the invaginating hypoblast, nodal, a member of TGF- $\beta$ super family secreted protein, has an essential role on the dorsal mesoderm determination (Yu et al., 2002a, Onai et al., 2010); loss of Nodal signaling resulted in absence of somites and the notochord. Between each rostral somite in the dorsal mesoderm, a faint border becomes distinct gradually; during the late gastrula to neurula stages, genes are expressed in somites as segmental manner or continuously (Table1) (Fig. 2).

In vertebrates, Notch signaling pathway controls segmental boundary formation in somitogenesis (Pourquie, 2011). In the amphioxus, similar to vertebrates, Notch component genes (e.g. delta, hairy) are expressed segmentally in the rostral or caudal border of somites (Minguillon et al., 2003, Rasmussen et al., 2007). Consistent with the expression pattern, suppression of Notch signaling in the amphioxus resulted in disruption of segmental boundary formation in somites; paraxial mesodermal cells were distorted and arranged irregularly (Onai et al., 2015b). Whereas in Notch signaling disrupted embryos, the expression level of 

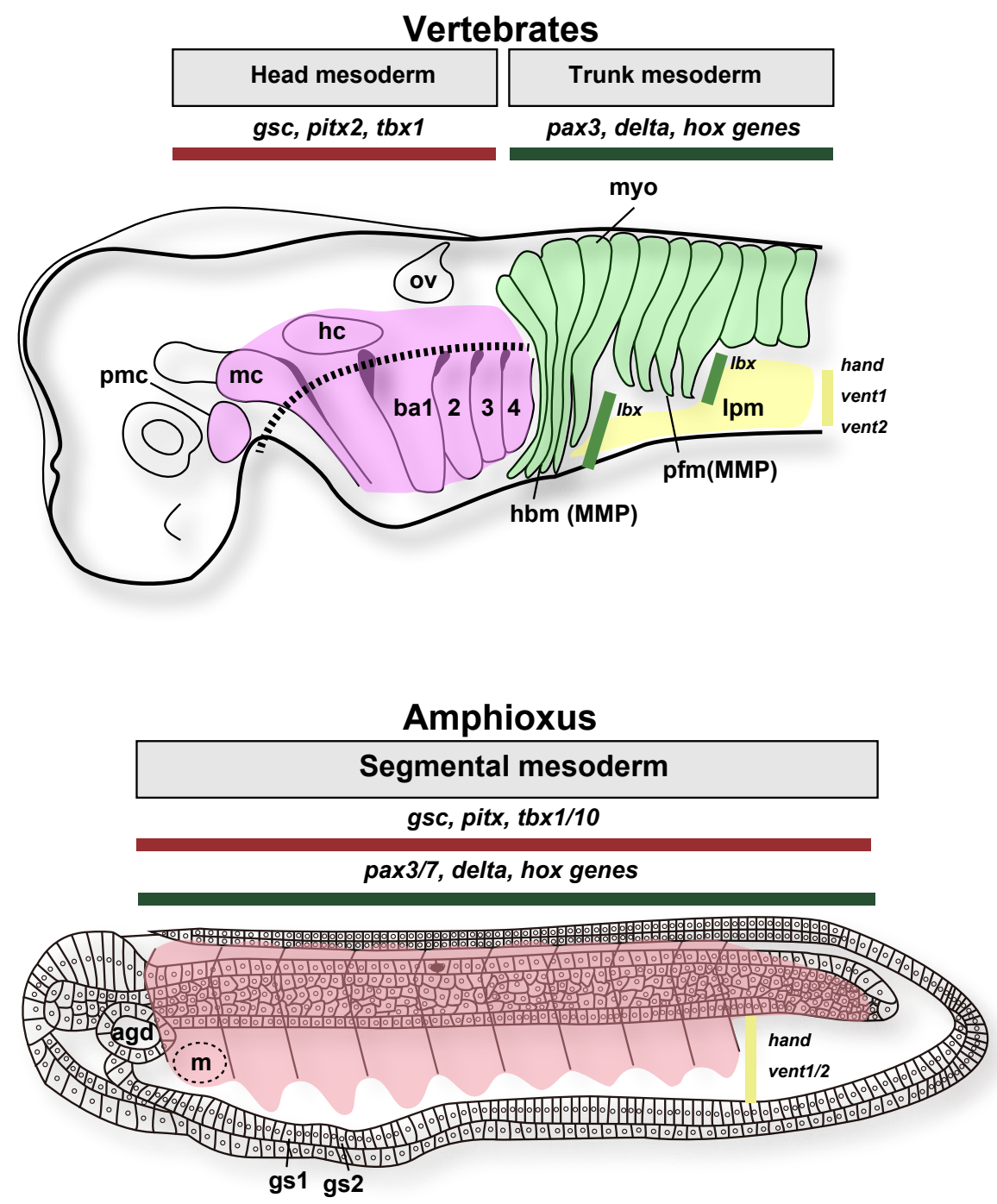

Fig. 2. Evolution of the vertebrate head/trunk mesoderm. In the amphioxus, the segmental mesoderm (somites) arises in the dorsal hypoblast and expresses two mesodermal gene groups (red and green). By the mid neurula, the segmental mesoderm sends ventral extension into the pharyngeal area that expresses yellow genetic components such as hand, vent $1 / 2$. In vertebrates, the head and trunk mesoderm differentiate during gastrula stages and key mesodermal genetic groups (red, green) are separated in the head and trunk. In the head mesoderm, there are three coelomic cavities in some vertebrates that are probably synapomorphy of gnathostomes (Adachiet al., 2012). The head mesoderm can be divided into the dorsal and ventral part (dotted line) from the morphological view. Tbx 1 is expressed in the ventral part of the head mesoderm. In amphioxus, tbx1/10 is also expressed in the ventral mesoderm but the expression domain is overlapped with hand, suggesting that A/P genetic polarization occurred in the ventral mesoderm of vertebrates as well as the dorsal mesoderm. In the trunk, the lateral plate mesoderm develops during gastrula stage that expresses vent gene. In the myotomes, migrating muscle precursor (MMP) cells migrate ventrally which form the hypobranchial or pectoral fin muscles. These cells expresses lbx gene that is a paralog of vent (Neyt et al., 2000, Kozmik et al., 2001). Therefore, the vertebrate may have evolved MMP cells by recapitulating the ventral mesodermal patterning seen in the amphioxus. In this process, the vertebrate might have innovated earlier differentiation of the ventral mesoderm compared with amphioxus. muscle differentiation gene muscle-actin was elevated compared with the wild type (Onai et al., 2015b). Therefore, Notch signaling has an important role not only in segmental border formation between somites but also in specification of somites in the amphioxus (Onai et al., 2015b).

Another key signaling pathway for somitogenesis is FGF signaling in vertebrates (Pourquie, 2011). In the amphioxus, fgf8/17/18 was expressed in the dorsal mesoderm during gastrula stages; FGF signaling pathway was essential for the rostral three somites differentiation (Bertrand et al., 2011). However, more caudal somites were little affected when FGF signaling was inhibited (Bertrand et al., 2011).

In the caudal somites developing from the tail bud, same genes (notch, fgfs, wnts) are expressed as seen in the rostral somites (Table1)(Fig. 1B). In the tail bud, there are presumably different types of cells such as undifferentiated stem cells and cells gained positional information to differentiate somites or the notochord. In histology, differences of these cell shapes were not clear (Schubert et al., 2001). Even so, Bfwnt3 was localized in the posterior tail bud, suggesting that Bfwnt3 may control differentiation of cells in the tail bud (Schubert et al., 2001). Supporting this notion, excess
$W n t / \beta$-catenin signaling from the early gastrula stage delayed the onset of muscle-actin expression in somites (Onai et al., 2012). Also the functional study of Notch signaling showed that Notch had an essential role in segmental border formation in the caudal somites (Onai et al., 2015b).

The accumulation of genetic knowledge on somitogenesis promoted our understanding on how somites are specified in amphioxus embryos. But many developmental events in somitogenesis have not been examined at the molecular level. For examples: (1) Formation of the paraxial mesoderm folding from the late gastrula to neurula stages (2) Determination of edge of each somite (3) Segregation mechanisms between somites (4) Cavity formation in somites. In the future study, these events should be explained from genetic mechanisms and cell biological (e.g. transformation of extracellular matrix, cell migration) aspects.

\section{The ventral mesoderm: oro-branchial muscles, blood vessels, cartilages}

During somite formation, each somite is regionalized along with the D/V and M/L axes. By the late neurula stage, the medial 
side of somites differentiates into myotome whereas the lateral side becomes the external cell layer (Mansfield et al., 2015). The ventral part of the external cell layer consists of cells migrating ventrally that sometimes named the ventral mesoderm or the lateral plate mesoderm (Kozmik et al., 2001, Mansfield et al., 2015). Recent transmission electron microscopy (TEM) study showed that the ventral mesoderm reached base of the ventral end and was separated into somatic (parietal) and splanchnic mesoderm (Kozmik et al., 2001). Probably these cells differentiate into connective tissues and striated muscles near the mouth and gill slits as well as blood vessels (Pascual-Anaya et al., 2013, Yasui et al., 2014, Mansfield et al., 2015).

At the three gill slits larva stage, gill muscles appear around the gill slits in the right side (Yasui et al., 2014). During metamorphosis, the primary and secondary gill slits move drastically and gill muscles degenerate rapidly (Yasui et al., 2014). After metamorphosis, the pterygial muscles, which surround the atrium and work to expel water from it, arise in the pterygocoel (Ruppert, 1997). Developmental origin of the pterygial muscles is not sure. In the atrium, smooth muscles are found in the endostylar artery; the genital coelom; the lateral flagella between gill and tongue bars; cells derived from the ventral mesoderm may be the source of these smooth muscles (Ruppert, 1997).

In the amphioxus, the mouth is induced at the left side of the body near the 1st somite (Hatschek, 1881). Striated muscles develop inside of the epidermis near the mouth opening, which are probably derived from the ventral extension of the left side of the 1st somite and will disappear during metamorphosis (Yasui et al., 2014). Therefore, the left 1st somite is very unique compared with other somites; some authors considered this somite was homologous to the mandibular mesoderm in vertebrates (MacBride, 1897, Masterman, 1898). During metamorphosis, the mouth migrates anteromedially, and the oral cirri from the mouth and velum in the pharynx, filled with striated muscles, arise (Willey, 1891, Ruppert, 1997).

The amphioxus does not have a distinct heart with inflow and outflow tracts (Ruppert, 1997). Instead, the amphioxus has many pumping vessels, derived from the ventral mesoderm, throughout the body (Ruppert, 1997, Holland et al., 2003). This is one of the major differences between vertebrates and the amphioxus circulatory systems. Even so, similar to the vertebrates, the amphioxus venus sinus is located just posterior to the gill slits (Ruppert, 1997). While in tunicates, the heart is situated posterior to gill slits, and centralized, but much less complex than that of vertebrates; it is intriguing to know how the centralized heart evolved from chordate ancestors (Ruppert, 1997).

Developmental genes expressed in the amphioxus ventral mesoderm have been isolated (Table1). By the mid neurula stage, a homolog of the vertebrate ventral mesoderm related homeobox gene vent $1 / 2$ expression is detected in the protruding ventral mesoderm (Kozmik et al., 2001). After migration, the ventral mesoderm in the pharynx expresses differentiation genes homologous to vertebrate neural crest cartilage genes such as twist, ets and cola (Table1) (Meulemans and Bronner-Fraser, 2007, Le Douarin and Kalcheim, 2009). In vertebrates, skeletal elements in the pharyngeal region are derived from the neural crest cells (Kuratani, 2012). In the amphioxus, gill bar composition is controversial; it maybe collagenous or chitinous tissues probably derived from the ventral mesoderm (Leuckart and Paenstecher, 1858, Weiss, 1890, Rahr, 1982). If the ancestral condition of the vertebrate gill skeleton had been amphioxus-like, then genetic programs for making skeletons in gill bars may have been transferred to the neural crest (Meulemans and Bronner-Fraser, 2007). While it is unknown to what extend the visceral skeleton was originated from the neural crest in ancestral vertebrates. Cells in the head mesoderm might have contributed. In tunicates, neural crest like cells differentiate into pigment and neurons, but not clear whether it will form connective tissues in gill slits (Abitua et al., 2012, Stolfi et al., 2015).

In vertebrates, the transcriptional factor hand is expressed in the lateral plate mesoderm (Onimaru et al., 2011). The amphioxus homolog of hand is detected in the ventral mesoderm and Onimaru et al., proposed the homology between the ventral mesoderm in amphioxus and the lateral plate mesoderm in vertebrates (Onimaru et al., 2011). While in the amphioxus, the ventral mesoderm has the expression domain of $t b x 1 / 10$, a homolog of branchial arch mesodermal gene tbx1 in vertebrates (Adachi et al., 2012, Onai et al., 2015a). Whether or not $t b \times 1 / 10$ and hand are co-expressed is not known; the overlapped expression domains along with the A/P axis of these genes, even they might not be co-expressed, indicates that the amphioxus ventral mesoderm has both the branchial and lateral plate mesodermal properties in vertebrates; as is the case in the rostral somites in the amphioxus, which have both head and trunk mesodermal properties in vertebrates (Onai et al., 2015a).

\section{Branchiomerism; development of gill slits, the anterior gut diverticulum (agd), the club-shaped gland and the endostyle in the amphioxus}

Differentiation of somites starts during gastrula stage in the amphioxus (Table1). Through the neurula to larva stages, myotomes develop segmentally along with the A/P axis. The ventral mesoderm derived from the somites extends to the pharynx and intestine in the amphioxus (Holland et al., 2003, Holland and Onai, 2011, Yasui et al., 2014). In the visceral system, there are segments arising from the gut wall. These segments include gill slits, the agd, the club-shaped gland and the endostyle.

\section{Gill slits}

Gill slits form by the thirteen somites stage (Fig. 1) (Hatschek, 1881). The sign of first gill slit arises as a right endodermal fold below the second somites (Fig. 1) (Hatschek, 1881). During early larva stages, anterior three gill slits protrude to the outside (Fig. 1) (Holland and Holland, 1996, Yasui et al., 2014). In the amphioxus, more than ten gill slits develop in the right side (the primary gill slits) and during metamorphosis, the secondary gill slits arise that are arranged symmetrically after metamorphosis (Willey, 1891). After the three to four gill slits form, it takes a while before more caudal ones start to differentiate (Willey, 1891, Yasui et al., 2014). Gill muscles are well developed when the three gill slits form (Yasui et al., 2014). When seventeenth gill slits are formed, each gill muscle is located as a segmental manner, and seems to organize a single metameric unit with myotomes (Goldschmid, 1905, Yasui et al., 2014).

In the amphioxus, genes expressed in the gill slits also participate in somitogenesis (Table 1 and Table 2). Whereas pax1/9, a paired box family member, is specifically expressed in the anterior endoderm except for gill opening regions (Holland and Holland, 
1996). The expression pattern of pax $1 / 9$ indicates that this gene is essential for specification of gill slits. Upstream signaling pathway of pax1/9 is probably retinoic acid (RA) signaling that is important for gill slits formation in the amphioxus (Holland and Holland, 1996). When the embryos were treated with RA, gill slits disappeared, and pax 1/9 expression was not down regulated in the prospective gill opening regions (Holland and Holland, 1996). RA signaling also controlled hox 1 expression in the anterior endoderm (Holland and Holland, 1996). Hox code is known as a genetic code for giving positional information to cells; and precise location of gill slits are controlled by RA signaling and Hox code (Holland and Holland, 1996). Although many genes expressed in gill slits or the mesoderm

TABLE 2

\section{KEY GENES FOR BRANCHIOSMERISM}

\begin{tabular}{|c|c|c|c|c|c|c|}
\hline \multicolumn{7}{|l|}{ Agd } \\
\hline Gene name & Late gastrula & Early neurula & Mid neurula & Late neurula & Early larva & Refs \\
\hline$g s c$ & 0 & 0 & - & - & - & $Y u(2007)$ \\
\hline $\operatorname{six} 1 / 2$ & $\mathrm{O}$ & $\mathrm{O}$ & $\mathrm{O}$ & $\mathrm{O}$ & $x$ & Kozmik(2007) \\
\hline $\operatorname{six} 3 / 6$ & $\mathrm{O}$ & $\mathrm{O}$ & $\mathrm{O}$ & $\mathrm{O}$ & $\mathrm{O}$ & Kozmik(2007) \\
\hline six $4 / 5$ & $\mathrm{O}$ & $\mathrm{O}$ & $\mathrm{O}$ & - & 0 & Kozmik(2007) \\
\hline eya & 0 & $x$ & - & 0 & 0 & Kozmik(2007) \\
\hline hex & $\mathrm{O}$ & $x$ & $x$ & $x$ & $x$ & Onai(2009) \\
\hline$o t x$ & O & 0 & 0 & 0 & O Onail & ai(2009), Schubert(2008 \\
\hline pitx & 0 & 0 & 0 & 0 & 0 & Yasui(2000) \\
\hline рах3/7 & 0 & 0 & 0 & $x$ & $x$ & Holland(1999) \\
\hline notch & $x$ & 0 & 0 & 0 & 0 & Holland(2001) \\
\hline delta & $x$ & $\mathrm{O}$ & $\mathrm{O}$ & $x$ & $x$ & Rasmussen(2007) \\
\hline pit1 & $x$ & $x$ & 0 & 0 & 0 & candiani(2008) \\
\hline \multicolumn{7}{|l|}{ Gill slit } \\
\hline six $1 / 2$ & & 0 & 0 & 0 & 0 & Kozmik(2007) \\
\hline $\operatorname{six} 4 / 5$ & & $\mathrm{O}$ & 0 & 0 & 0 & Kozmik(2007) \\
\hline eya & & $x$ & - & 0 & 0 & Kozmik(2007) \\
\hline$t b \times 1 / 10$ & & $x$ & $\mathrm{O}$ & 0 & $\mathrm{O}$ & Mahadevan(2004) \\
\hline delta & & $x$ & $x$ & $\mathrm{O}$ & $x$ & Rasmussen(2007) \\
\hline$f g f 8 / 17 / 18$ & & - & - & $\mathrm{O}$ & 0 & Meulemans(2007) \\
\hline pax1/9 & & 0 & 0 & 0 & 0 & Liu(2015) \\
\hline pax2/5/8 & & $x$ & $x$ & $\mathrm{O}$ & 0 & Kozmik(1999) \\
\hline \multicolumn{7}{|l|}{ Mouth } \\
\hline pou4 & & & $x$ & $\mathrm{O}$ & $\mathrm{O}$ & Candiani(2006) \\
\hline $\lim 1 / 5$ & & & $\mathrm{O}$ & 0 & 0 & Langeland(2006) \\
\hline pc6c & & & - & - & 0 & Bertrand(2006) \\
\hline$d k k 1 / 2 / 4$ & & & - & $\mathrm{O}$ & 0 & Soukup(2015) \\
\hline pax2/5/8 & & & $x$ & $\mathrm{O}$ & $\mathrm{O}$ & Kozmik(1999) \\
\hline six4/5 & & & $x$ & - & 0 & Kozmik(2007) \\
\hline$f g f 8 / 17 / 18$ & & & $x$ & $\mathrm{O}$ & 0 & Meulemans(2007) \\
\hline nodal & & & 0 & 0 & 0 & $Y u(2002)$ \\
\hline pitx & & & 0 & 0 & 0 & Yasui(2000) \\
\hline \multicolumn{7}{|c|}{ Club-shaped gland } \\
\hline foxe4 & & $\mathrm{O}$ & $\mathrm{O}$ & $\mathrm{O}$ & $\mathrm{O}$ & Yu(2002) \\
\hline delta & & $x$ & $x$ & 0 & 0 & Rasmussen(2007) \\
\hline fgfr1 & & 0 & 0 & 0 & 0 & Bertrand(2009) \\
\hline $\operatorname{six} 1 / 2$ & & $\mathrm{O}$ & 0 & 0 & 0 & Kozmik(2007) \\
\hline$p c 6 c$ & & $x$ & - & - & 0 & Bertrand(2006) \\
\hline \multicolumn{7}{|l|}{ Endostyle } \\
\hline$t t f 1(n k 2-1)$ & & 0 & 0 & 0 & 0 & Venkatesh(1999) \\
\hline hex & & $\bigcirc$ & $\bigcirc$ & $\mathrm{O}$ & 0 & Onai(2009)(2010) \\
\hline six $4 / 5$ & & $x$ & $x$ & - & $\mathrm{O}$ & Kozmik(2007) \\
\hline pax2/5/8 & & $x$ & $x$ & 0 & 0 & Kozmik(1999) \\
\hline fgfa & & 0 & 0 & 0 & 0 & Bertrand(2011) \\
\hline
\end{tabular}

in the pharynx have been reported, their exact functions are little known except for tbx1/10 and pax1/9 (Koop et al., 2014, Liu et al., 2015). How genetic systems regulate segmentation of gill slits is still largely unsolved; the asymmetrical formation of gill slits, together with the large numbers, is one of the most interesting features of the amphioxus branchiomerism, few molecular studies have been done on these developmental events so far.

\section{The anterior gut diverticulum}

The agd is regionalized in the dorsoanterior hypoblast just anterior to rostral somites by the late gastrula stage (Fig. 1A) (Hatschek, 1893). By the stage when rostral somites are morphologically obvious, the agd, separated from the anterior gut wall, shifts ventroposteriorly with the anterior extension of the rostral somites and notochord (Fig. 1A) (Hatschek, 1893). Soon after the agd is separated from the gut, it is divided into the left and right coeloms and the right one will become the rostral coelom of the larva, but will degenerate during metamorphosis (Hatschek, 1881, Willey, 1891). The left agd fuses with the epidermis to conduct the preoral pit (Hatschek, 1881). The preoral pit has monociliated cells, and has been thought as a sense organ or glandular cells (Stach, 1996, Candiani et al., 2008). The preoral pit later moves into the mouth and will form the Hatschek's pit (an adenohypophisis homolog of vertebrates) just beneath the brain as well as the wheel organ (Stach, 1996).

At the molecular level, the presumptive agd expresses both the dorsal mesodermal markers (e.g. gsc, six3/6, pax3/7) and the endodermal genes (e.g. otx, hex, pax1/9) (Fig. 1B)(Table 1 and Table 2); six3/6, pax3/7 expression patterns have been kept until the early larva stage. This suggests that the agd is an endodermal structure but has the mesodermal and endodermal genetic identities (Fig. 1). By the five somites stage, the boundary between the caudal edge of the agd and the dorsal roof of archenteron becomes clear, and the agd expressed a segmental gene delta (Fig. 1A) (Rasmussen et al., 2007). This suggests that similar to somitogenesis, separation of the agd from the anterior gut is controlled by Notch signaling. After separation into left and right, the left agd has the two distinct gene expression domains along with the A/P axis: six3/6, eya, six $1 / 2$ are expressed in the rostral region and pax6, pit1 in the caudal one (Table 2)(Glardon et al., 1998, Kozmik et al., 2007, Candiani et al., 2008). Pit1 is a pituitary marker in vertebrates (Candiani 
et al., 2008). Whether or not the two expression domains dictate cell fates in the agd is unknown.

\section{The club-shaped gland}

The club-shaped glandular is an organ secreting mucus for food capturing in the pharynx. In development, primordium of the club-shaped gland arises by the nine somites stage in the right side of the alimentary canal below the 1st somite (Fig. 1A)(Hatschek, 1881). An endodermal fold of the club-shaped gland increases its size ventrally and reaches the left side (Hatschek, 1881). The club-shaped gland consists of two parts: dorsal glandular cells and the ventral duct that opens just beneath the mouth (Olsson, 1983). Cells in the duct have long cilia that produce a strong current, and thought as an internal pore or otherwise an external pore (Olsson, 1983, Lacalli, 2008). The recent study by using a ruthenium red has proved the club-shaped gland is an internal pore (Holland et al., 2008b). The gland has single layer of cells that contain many globules and rich microvilloid processes (Holland et al., 2008b). These cells secrete a mucosubstance (a neutral glycoprotein), for capturing food particles (Holland et al., 2008b). During metamorphosis, the club-shaped gland disappears (Holland et al., 2008b). Since the club-shaped gland is located near the endostyle, a homolog of the thyroid gland, it was considered as a thyroid homolog as well (Olsson, 1983). Interestingly, foxe 4 a homolog of vertebrate thyroid specific transcription factor-2 (TTF2) is expressed specifically in the developing club-shaped gland (Table 2)(Yu et al., 2002b). Since other chordates have no homologs of the club-shaped gland, the evolution of the club-shaped gland is unclear. Even so, the club-shaped gland expresses important genes for somitogenesis such as delta, fgfr1 (Table 2)(Fig. 1B) (Rasmussen et al., 2007). Therefore, it is possible that Notch and Fgf signaling control separation of the club-shaped gland primordium from other endodermal cells; in that case, segmental genes found in somitogenetis might have been co-opted.

\section{The endostyle}

The endostyle is a gland organ, used for food capture, which has been considered as a chordate common trait (Ruppert, 1997). The endostyle in the larval amphioxus is located just anterior to the club-shaped gland and arises as a right side fold from the eight to nine somites stages (Fig. 1A) (Hatschek, 1881). The amphioxus endostyle is highly ciliated and consists of two epithelial thick bands (Olsson, 1983). From the TEM study, cells in the endostyle have plenty of ER (Endoplasmic reticulum) and large granules (Olsson, 1983). In the apical region, the microvilli and single cilium are seen and cells secrete a mucoprotein by exocytosis (Olsson, 1983). During metamorphosis, the endostyle migrates into the ventral floor of the pharynx and becomes symmetrical (Willey, 1891). The endostyle is a vertebrate thyroid homolog, and the functional study indicates that it is essential for metamorphosis in the amphioxus (Paris et al., 2008).

During development, the endostyle expresses homeobox gene hex, an anterior endodermal marker in vertebrates (Onai et al., 2009). Hex is firstly expressed in the entire anterior endoderm at the gastrula stage, and during embryogenesis the expression domain is restricted to the presumptive endostyle (Onai et al., 2009). For differentiation of the endostyle, ttf1 ( $n k x 2.1)$, a thyroid related homeobox gene, is expressed in the anterior endoderm from the early neurula stage and later specifically expressed in the endostyle at the later stage (Table 2) (Venkatesh et al., 1999, Ogasawara et al., 2001). The endostyle also expresses amphioxus specific genes fgfa and fgfc (Bertrand et al., 2011). However, segmental genes such as delta, hairy are not expressed (Minguillon et al., 2003, Rasmussen et al., 2007). Therefore, the endostyle has very different developmental programs compared with somites and gill slits. Given that, the endostyle and club-shaped gland, once considered as a homolog of gill slits, might not be serial homologs of gill slits (Wijhe, 1914).

\section{Chordate somatic/visceral systems and vertebrate head evolution}

A visceral system cannot exist without a somatic system and vice versa in chordates. In terms of developmental origins, somatic and visceral systems are dependent on each other in the amphioxus; visceral musculatures and skeletal elements are probably derived from somites (Ruppert, 1997, Yasui et al., 2014). Enormous contributions of somatic elements to the visceral system in the amphioxus and similar cases in vertebrate embryos (for example, hypobranchial muscles derived from somites locate and connect ventral part of visceral skeletons) suggest that vertebrate somatic and visceral systems retain dependency between the two that might have evolved before the split of amphioxus from vertebrates (Romer, 1972).

In vertebrates, positional segregation of somitomerism and branchiomerism along with the A/P axis might have occurred that correlates with the head/trunk subdivision if ancestral vertebrates had been amphioxus-like (Fig. 2) (Kuratani, 1997, Conway Morris and Caron, 2014). In this process, two genetic groups in the mesoderm were likely to have been important (Fig. 2)(Onai et al., 2015a); genes responsible for segment formation seem to be in the group for trunk mesoderm, while such genes seem not to be involved in the head mesoderm formation. If so, during the extant vertebrate head evolution, mesodermal genes might have become separated spatially into two domains (one for the head and the other for the trunk) from an amphioxus-like ancestor (Kuratani, 2003).

When reconstructing the primitive vertebrates, fossil findings are informative. Even so, whether the first vertebrate was amphioxus-like or not is enigmatic; Mettaspriggina, a primitive vertebrate from a Cambrian stratum, had metameric W-shaped myotomes into the rostral end; but other stem vertebrates-Myllokunmingia, Haikouichthys-seemed not have myotomes in the rostral end (Conway Morris and Caron, 2014). Although the rostral structures of these fossils are not clear, often squashed, making it very difficult to reconstruct the actual shape. In addition to the first vertebrate, whether the first chordate is amphioxuslike is vague and controversial (Lacalli, 2012, Pani et al., 2012, Mallatt and Holland, 2013, Holland et al., 2015). One problem is that fossils, classified in stem chordates from the Cambrian period-about 500 million years ago, are limited, making it very difficult to reconstruct ancestral forms. Therefore, dependent on authors, a character matrix based cladistic analysis resulted in a different position of Pikaia, a Cambrian fossil known as a basal chordate (Mallatt and Holland, 2013). Regarding the amphioxus, the evolution of some traits including the agd is unclear. Since the agd is situated anterior to rostral somites and the notochord, 


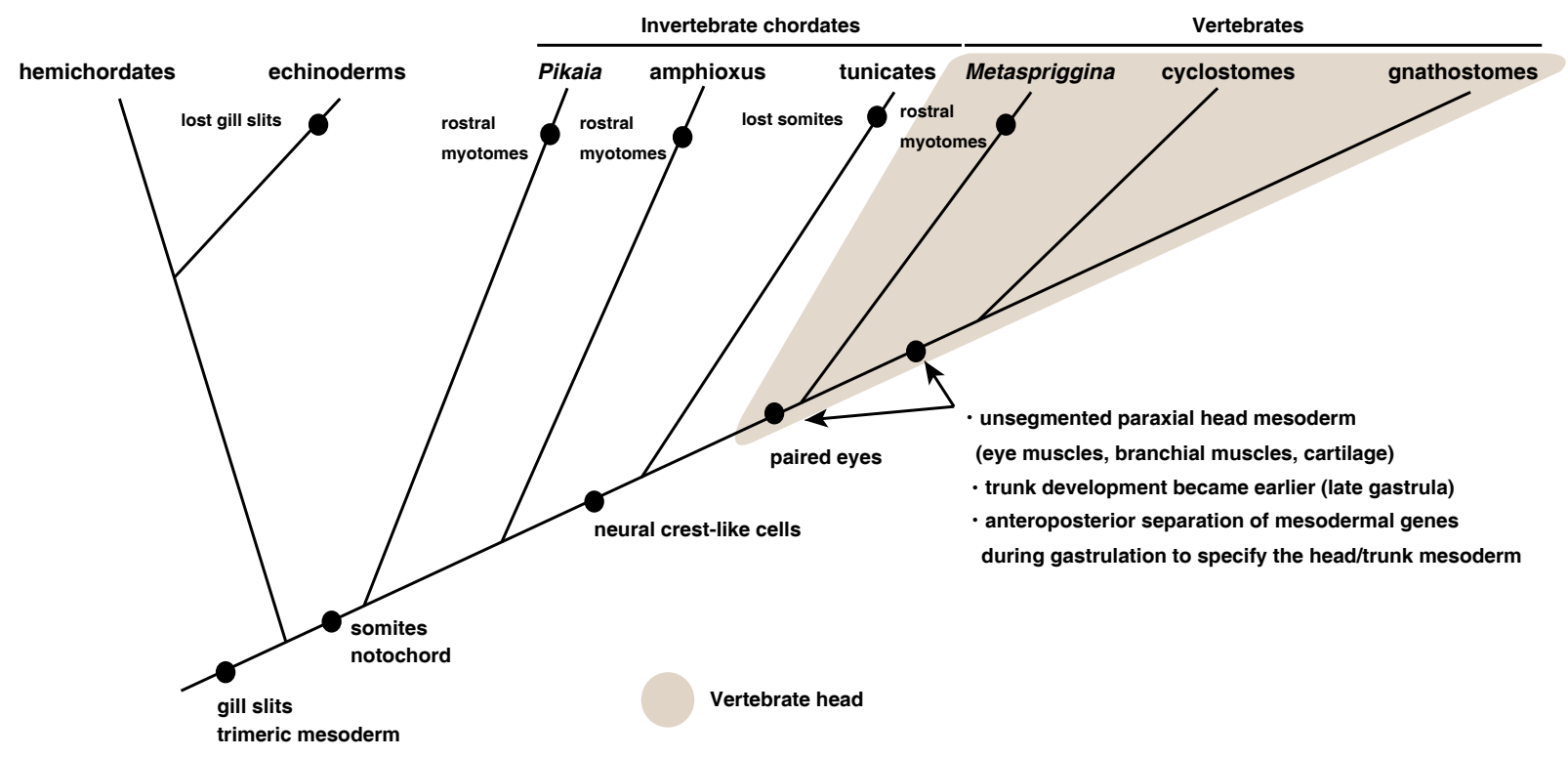

Fig. 3. An evolutionary scenario of the vertebrate head in deuterostomes. Before the evolution of the vertebrate head, key traits- gill slits, somites, the notochord, nerve cord and neural crest-like cells present in deuterostome ancestors. In vertebrates, head/trunk formation starts during the gastrula stage through A/P genetic segregation of the mesodermal genes; these genes are largely overlapped in the amphioxus gastrula. Through the A/P mesodermal gene segregation, skeletal muscles-eye muscles, branchial muscles and skulls might have formed to organize the head. Since Metaspriggina might have had a cranial cartilage lateral or rostral to the notochord (orbital or parachordal cartilage?), un-segmented head mesoderm could have evolved before the split of several vertebrate lineages.

several scientists have proposed that the agd is homologous to the premandibular head mesoderm in vertebrates and the protocoelic mesodermal cells in hemichordates (Masterman, 1898, Van Wijhe, 1902, Kuratani et al., 1999).

In hemichordates, mesoderm arises from the three separate regions (the protomere, mesomere, metamere) along with the A/P body axis (Morgan, 1891, Lowe et al., 2015); the tripartite mesoderm is also found in echinoderm larvae, suggesting the deuterostome grand plan. If this homology is correct, the agd may be an endodermal structure modified from the rostral mesoderm in an ancestral chordate, a part of which is specified into the preoral pit and later the adenohypophysis. The dorsal mesodermal and endodermal gene expression patterns in the agd fit with this scenario (Fig. 1). Based on the view, the agd is a segmental unit transferred from somatic into visceral. In evolution, transfers of embryonic character in segments from somatic to visceral system and vice versa may occur to generate a novel functional organ.

Although the agd might be an endodermal structure evolved from the protocoelic mesoderm, this does not mean that the extension of rostral somites to the anterior tip during development, is a derived condition, and the mesodermal formation in the amphioxus is nothing to do with the evolution of the vertebrate head/trunk mesoderm. As mentioned above (Fig. 2), separation of the paraxial mesodermal genes into the prospective head/trunk mesoderm of vertebrates occurs during gastrula stage, much earlier than the stage when somites and the notochord extend anteriorly, from mid neurula to larva stages, in the amphioxus (Onai et al., 2015a). Furthermore, separation of mesodermal genes anteroposterioly in vertebrate gastrulation seems to require the cell adhesion protein cadherin degradation complex FLRT3/ RND1 - FLRT3 is a membrane protein which binds to the small
GTPase RND1 - expressed in the involuting mesodermal cells that originate from the outer layer; this system might be a vertebrate innovation (Onai et al., 2015a). The amphioxus gastrulation is done by simple invagination with little involution (Zhang et al., 1997), and suppression of mesodermal involution in vertebrate embryos recapitulated amphioxus-like mesoderm formation (Onai et al., 2015a). Therefore, the evolution of the vertebrate head mesoderm might have occurred in gastrulating embryos of amphioxus-like ancestral vertebrates (Fig. 3).

\section{Conclusion and perspectives}

The vertebrate head problem, started as a comparative morphological question, is now addressed by molecular embryology. Historically, comparative morphologists tended to count number of segments in embryos, and had been troubled by cognitive bias. Adding molecular embryology changed the context of the problem, and has offered new perspectives to the problem. The major question is mesodermal organization and its evolution in the head in chordates. In the vertebrate head mesoderm evolution, a genetic segregation into an anterior and a posterior domain with contrasting patterns of developmental gene expression might have occurred in an ancestor of vertebrates; a new gastrulation movement, massive involution, is likely to be essential for this division of the anterior mesoderm into two developmental territories. However, exact genetic mechanisms for the event are not clear. Also if the latest common ancestor of chordates is amphioxus-like, when did the mesodermal patterning of them evolve? Did stem deuterostomes have already? To address such questions, it would be important to compere A/P mesodermal patterning between chordates and ambulacrarians. 


\section{Acknowledgements}

We thank to Dr. Y. Henmi, H. Shimasaki, A. Maenaka and K. Shimohira of Kumamoto Univ. for collecting adult amphioxus in Amakusa during April in 2016, and Dr. M. Okauchi of National Research Institute of Aquaculture for algea culture. This research was supported by a KAKENHI Grant-inAid for Scientific Research (A) from the Japan Society for the Promotion of Science (grant number 15H02416).

\section{References}

ABITUA, P.B., WAGNER, E., NAVARRETE, I.A. and LEVINE, M. (2012). Identification of a rudimentary neural crest in a non-vertebrate chordate. Nature 492: 104-107.

ADACHI, N., TAKECHI, M., HIRAI, T. and KURATANI, S. (2012). Development of the head and trunk mesoderm in the dogfish, Scyliorhinus torazame: Il. Comparison of gene expression between the head mesoderm and somites with reference to the origin of the vertebrate head. Evol Dev 14: 257-276.

ADOUTTE, A., BALAVOINE, G., LARTILLOT, N. and DE ROSA, R. (1999). Animal evolution. The end of the intermediate taxa? Trends Genet 15: 104-108.

AHLBORN, F. (1884). Über die Segmentation des Wirbelthierkörpers. Z. Wiss. Zool 309-330.

BALFOUR, F.M. (1878). A monograph on the development of elasmobranch fishes. Macmillan, London.

BEASTER-JONES, L., KALTENBACH, S.L., KOOP, D., YUAN, S., CHASTAIN, R. and HOLLAND, L.Z. (2008). Expression of somite segmentation genes in amphioxus: a clock without a wavefront? Dev Genes Evol 218: 599-611.

BERTRAND, S., CAMASSES, A., PARIS, M., HOLLAND, N.D. and ESCRIVA, H. (2006). Phylogenetic analysis of Amphioxus genes of the proprotein convertase family, including aPC6C, a marker of epithelial fusions during embryology. Int $\mathrm{J}$ Biol Sci 2: 125-132.

BERTRAND, S., SOMORJAI, I., GARCIA-FERNANDEZ, J., LAMONERIE, T. and ESCRIVA, H. (2009). FGFRL1 is a neglected putative actor of the FGF signaling pathway present in all major metazoan phyla. BMC Evol Biol 9: 226.

BERTRAND, S., CAMASSES, A., SOMORJAI, I., BELGACEM, M.R., CHABROL, O., ESCANDE, M.L., PONTAROTTI, P. and ESCRIVA, H. (2011). Amphioxus FGF signaling predicts the acquisition of vertebrate morphological traits. Proc Natl Acad Sci U S A 108: 9160-9165.

CANDIANI, S., HOLLAND, N.D., OLIVERI, D., PARODI, M. and PESTARINO, M. (2008). Expression of the amphioxus Pit-1 gene (AmphiPOU1F1/Pit-1) exclusively in the developing preoral organ, a putative homolog of the vertebrate adenohypophysis. Brain Res Bull 75: 324-330.

CANDIANI, S., OLIVERI, D., PARODI, M., BERTINI, E. and PESTARINO, M. (2006). Expression of AmphiPOU-IV in the developing neural tube and epidermal sensory neural precursors in amphioxus supports a conserved role of class IV POU genes in the sensory cells development. Dev Genes Evol 216: 623-633.

CONWAY MORRIS, S. and CARON, J.B. (2014). A primitive fish from the Cambrian of North America. Nature 512: 419-422.

DAMAS, H. (1944). Recherches sur le dévellopement de Lampetra fluviatilis L. Contribution à l'étude de la Céphalogenèse des vertébrés. Arch. Biol. 55: 1-248 + pl. I-III.

DE BEER, G. (1947). Edwin Stephen Goodrich 1868-1946. Obituary Notices of Fellows of the Royal Society 5: 477-490.

DE BEER, G.R. (1922). The segmentation of the head in Squalus acanthias.. $Q J$ Microsc. Sci. 66: 458-474.

DEAN, B. (1899). On the embryology of Bdellostoma stouti. In Festschrift zum siebenzigsten Geburtstag von Carl von Kupffer. Gustav Fischer, Jena, pp.221$276+$ pl. XV-XXVI.

GEE, H. (1996). Before the backbone: Views on the origin of the vertebrates. Chapman and Hall, London.

GEGENBAUR, C. (1871). Ueber die Kopfnerven von Hexanchus und ihre Verhältniss zur "Wirbeltheorie" des Schädels. Jena Z. Med. Naturwiss. 6: 497-599.

GEGENBAUR, C. (1872). Untersuchungen zur vergleichenden Anatomie der Wirbelthiere. 3. Heft:Das Kopfskelet der Selachier, als Grundlage zur Beurtheilung der Genese des Kopfskeletes derWirbelthiere. Verlag von Wilhelm Engelmann, Leipzig.

GEGENBAUR, C. (1887). Die Metamerie des Kopfes und die Wirbeltheorie des kopfskelets. Morphol. jb. 13: 1-114.
GILBERT, P.W. (1952). The origin and development of the head cavities in the human embryo. J. Morphol. 90: 149-187.

GLARDON, S., HOLLAND, L.Z., GEHRING, W.J. and HOLLAND, N.D. (1998). Isolation and developmental expression of the amphioxus Pax-6 gene (AmphiPax-6): insights into eye and photoreceptor evolution. Development 125: 2701-2710.

GOETHE, J.W. (1790). Das Schädelgrüt aus sechs Wirbelknochen aufgebaut. zur naturwissenschaft überhaupt, besonders zur morphologie. II 2 (cited in Gaupp 1898).

GOLDSCHMID, R. (1905). "Amphioxides". Wiss Ergeb Dtsch Tiefsee- Expedition 12: 1-92.

GOODRICH, E.S. (1918). On the development of the segments of the head in Scyllium.. Quart. J. micr. Sci. 63: 1-30.

GOODRICH, E.S. (1930). Studies on the Structure and Development of Vertebrates. Macmillan, London.

GÖTTE, A. (1875). Atlas zur entwickelungsgeschichte der unke (Bominator igneus) als grundlage: einer vergleichenden morphologie der wirbelthiere. L. Voss, Leipzig.

HATSCHEK, B. (1881). Studien über entwicklung des Amphioxus. Wien, A. Hölder.

HATSCHEK, B. (1893). The Amphioxus and its development. Translated and edited by James Tuckey. London:Swan, Sonnenschein \& co.

HOLLAND, L.Z. (2016). Tunicates. Curr Biol 26: R146-152.

HOLLAND, L.Z. and HOLLAND, N.D. (1996). Expression of AmphiHox-1 and AmphiPax-1 in amphioxus embryos treated with retinoic acid: insights into evolution and patterning of the chordate nerve cord and pharynx. Development 122: 1829-1838.

HOLLAND, L.Z., HOLLAND, N.D. and GILLAND, E. (2008a). Amphioxus and the evolution of head segmentation. Integr Comp Biol 48: 630-646.

HOLLAND, L.Z., KENE, M., WILLIAMS, N.A. and HOLLAND, N.D. (1997). Sequence and embryonic expression of the amphioxus engrailed gene (AmphiEn): the metameric pattern of transcription resembles that of its segment-polarity homolog in Drosophila. Development 124: 1723-1732.

HOLLAND, L.Z. and ONAI, T. (2011). Early development of cephalochordate (amphioxus). WIREs Dev. Biol. 1: 167-183

HOLLAND, L.Z., RACHED, L.A., TAMME, R., HOLLAND, N.D., KORTSCHAK, D., INOKO, H., SHIINA, T., BURGTORF, C. and LARDELLI, M. (2001). Characterization and developmental expression of the amphioxus homolog of Notch (AmphiNotch): evolutionary conservation of multiple expression domains in amphioxus and vertebrates. Dev Biol 232: 493-507.

HOLLAND, L.Z., SCHUBERT, M., KOZMIK, Z. and HOLLAND, N.D. (1999). AmphiPax3/7, an amphioxus paired box gene: insights into chordate myogenesis, neurogenesis, and the possible evolutionary precursor of definitive vertebrate neural crest. Evol Dev 1: 153-165.

HOLLAND, N.D., HOLLAND, L.Z. and HOLLAND, P.W. (2015). Scenarios for the making of vertebrates. Nature 520: 450-455.

HOLLAND, N.D., PARIS, M. and KOOP, D. (2008b). The club-shaped gland of amphioxus: Export of secretion to the pharynx in pre-metamorphic larvae and apoptosis during metamorphosis. Acta Zoologica 90: 372-379.

HOLLAND, N.D., VENKATESH, T.V., HOLLAND, L.Z., JACOBS, D.K. and BODMER, R. (2003). AmphiNk2-tin, an amphioxus homeobox gene expressed in myocardial progenitors: insights into evolution of the vertebrate heart. Dev Biol255: 128-137.

HUXLEY, T.H. (1858). The Croonian Lecture: On the theory of the vertebrate skull. Proc. Zool. Soc. London 9: 381-457.

JACOBSON, A.G. (1988). Somitomeres: Mesodermal segments of vertebrate embryos. Development 104: 209-220.

JARVIK, E. (1980). Basic Structure and Evolution of Vertebrate. vol 2,. Academic Press, Chicago and London 42-76.

JOLLIE, M. (1962). Chordate morphology. Reinhold, New York.

KINGSBURY, B.F. and ADELMANN, H.B. (1924). The morphological plan of the head Quart. J. Microscop. Sci. 68: 239-285.

KINGSBURY, B.F. Branchiomerism and the theory of head segmentation. J. Morph 42: 83-109.

KOLTZOFF, N.K. (1902). Entwickelungsgeschichte des Kopfes von Petromyzon planeri; ein Beitrag zur Lehre über Metamerie des Wirbelthierkopfes. Bull. Soc. Imp. Nat. Moscou 16: 259-589 + pl I-VII.

KoOP, D., CHEN, J., THEOdosiou, M., CARVALHO, J.E., ALVAREZ, S., DE LERA, A.R., HOLLAND, L.Z. and SCHUBERT, M. (2014). Roles of retinoic acid 
and Tbx1/10 in pharyngeal segmentation: amphioxus and the ancestral chordate condition. Evodevo 5: 36.

KOZMIK, Z., HOLLAND, L.Z., SCHUBERT, M., LACALLI, T.C., KRESLOVA, J., VLCEK, C. and HOLLAND, N.D. (2001). Characterization of Amphioxus AmphiVent, an evolutionarily conserved marker for chordate ventral mesoderm. Genesis 29: 172-179.

KOZMIK, Z., HOLLAND, N.D., KALOUSOVA, A., PACES, J., SCHUBERT, M. and HOLLAND, L.Z. (1999). Characterization of an amphioxus paired box gene, AmphiPax2/5/8: developmental expression patterns in optic support cells, nephridium, thyroid-like structures and pharyngeal gill slits, but not in the midbrain-hindbrain boundary region. Development 126: 1295-1304.

KOZMIK, Z., HOLLAND, N.D., KRESLOVA, J., OLIVERI, D., SCHUBERT, M., JONASOVA, K., HOLLAND, L.Z., PESTARINO, M., BENES, V. and CANDIANI, S. (2007) Pax-Six-Eya-Dach network during amphioxus development: conservation in vitro but context specificity in vivo. Dev Biol 306: 143-159.

KURATANI, S. (1997). Spatial distribution of postotic crest cells defines the head/trunk interface of the vertebrate body: embryological interpretation of peripheral nerve morphology and evolution of the vertebrate head. Anat Embryol (Berl) 195: 1-13.

KURATANI, S. (2003). Evolutionary Developmental Biology and Vertebrate Head Segmentation: A perspective from developmental constraint. Theory Biosci. 122: $230-251$

KURATANI, S. (2008). Is the vertebrate head segmented?-evolutionary and developmental considerations. Integr Comp Biol 48: 647-657.

KURATANI, S. (2012). Evolution of the vertebrate jaw from developmental perspectives. Evol Dev 14: 76-92.

KURATANI, S. and ADACHI, N. (2016). What are Head Cavities? - A History of Studies on Vertebrate Head Segmentation. Zoolog Sci 33: 213-228.

KURATANI, S., HORIGOME, N. and HIRANO, S. (1999). Developmental morphology of the head mesoderm and reevaluation of segmental theories of the vertebrate head: evidence from embryos of an agnathan vertebrate, Lampetra japonica. Dev. Biol. 210: 381-400.

KUSAKABE, R., KUSAKABE, T., SATOH, N., HOLLAND, N.D. and HOLLAND, L.Z. (1997). Differential gene expression and intracellular mRNA localization of amphioxus actin isoforms throughout development: Lmplications for conserved mechanisms of chordate development. Dev. Genes Evol. 207: 203-215.

LACALLI, T.C. (2008). Mucus secretion and transport in amphioxus larvae: organization and ultrastructure of the food trapping system, and implications for head evolution. Acta Zoologica 89: 219-230.

LACALLI, T.C. (2012). The Middle Cambrian fossil Pikaia and the evolution of chordate swimming. Evodevo 3: 12.

LANGELAND, J.A., HOLLAND, L.Z., CHASTAIN, R.A. and HOLLAND, N.D. (2006). An amphioxus LIM-homeobox gene, AmphiLim1/5, expressed early in the invaginating organizer region and later in differentiating cells of the kidney and central nervous system. Int J Biol Sci 2: 110-116.

LE DOUARIN, N. and KALCHEIM, C. (2009). The Neural Crest (Developmental and Cell Biology Series) 2nd Edition. Cambridge University Press 1-472.

LEUCKART, R. and PAENSTECHER, A. (1858). Untersuchungen über niedere Seethiere, Amphioxus lanceolatus. Archiv für Anatomie, Physiologie und wissenscaftliche Mecicin 558-569 + pl XVIII.

LIU, X., LI, G., LIU, X. and WANG, Y.Q. (2015). The role of the Pax1/9 gene in the early development of amphioxus pharyngeal gill slits. J Exp Zool B Mol Dev Evol 324: $30-40$

LOWE, C.J., CLARKE, D.N., MEDEIROS, D.M., ROKHSAR, D.S. and GERHART, J. (2015). The deuterostome context of chordate origins. Nature 520: 456-465.

MACBRIDE, E.W. (1897). The relationship of amphioxus to Balanoglossus. Proc. Cambridge. Philos. Soc. 9: 309-313.

MAHADEVAN, N.R., HORTON, A.C. and GIBSON-BROWN, J.J. (2004). Developmental expression of the amphioxus Tbx1/ 10 gene illuminates the evolution of vertebrate branchial arches and sclerotome. Dev Genes Evol 214: 559-566.

MALLATT, J. and HOLLAND, N. (2013). Pikaia gracilens Walcott: stem chordate, or already specialized in the Cambrian? J Exp Zool B Mol Dev Evol 320: 247-271.

MANSFIELD, J.H., HALLER, E., HOLLAND, N.D. and BRENT, A.E. (2015). Development of somites and their derivatives in amphioxus, and implications for the evolution of vertebrate somites. Evodevo 6: 21.

MASTERMAN, A.T. (1898). On the theory of archimeric segmentation and its bearing upon the phyletic classification of the coelomata. Proc. R. Soc. Edinb. 22:270-310.
MCMURRICH, J.P. (1912). The problem of the vertebrate head in the light of comparative anatomy. In Proc. 7th Internat. Zool. Cong., Boston, (ed., pp. 167-176. Boston, 19-24 August 1907: Cambridge Univeristy Press, Cambridge.

MEIER, S. (1979). Development of the chick embryo mesoblast. Formation of the embryonic axis and establishment of the metameric pattern. Dev Biol 73: 24-45.

MEIER, S. and TAM, P.P. (1982). Metameric pattern development in the embryonic axis of the mouse. I. Differentiation of the cranial segments. Differentiation 21: 95-108.

MEULEMANS, D. and BRONNER-FRASER, M. (2007). Insights from amphioxus into the evolution of vertebrate cartilage. PLoS One 2: e787.

MINGUILLON, C., JIMENEZ-DELGADO, S., PANOPOULOU, G. and GARCIAFERNANDEZ, J. (2003). The amphioxus Hairy family: differential fate after duplication. Development 130: 5903-5914.

MITSUKURI, K. (1893). Further Studies on the Formation of the Germinal Layers in Chelonia. Journal of the College of Science, Imperial University, Japan 5: 32-52.

MORGAN, T.H. (1891). The growth and metamorphosis of tornaria. J. Morphol. 5: 407-458.

NEAL, H.V. and RAND, H.W. (1936). The head problem. In Comparative Anatomy Philadelphia, pp.607-627.

NEYT, C., JAGLA, K., THISSE, C., THISSE, B., HAINES, L. and CURRIE, P.D. (2000). Evolutionary origins of vertebrate appendicular muscle. Nature 408:82-86.

OGASAWARA, M., SHIGETANI, Y., SUZUKUI, S., KURATANI, S. and SATOH, N (2001). Expression of thyroid transcription factor-1 (TTF-1) gene in the ventral forebrain and endostyle of the agnathan vertebrate, Lampetra japonica. Genesis 30: $51-58$

OKEN, L. (1807). Über die Bedeutung der Schädelknochen. Göbhardt, Bamberg.

OLSSON, R. (1983). Club-Shaped Gland and Endostyle in Larval. Branchiostoma lanceolatum (Cephalochordata). Zoomorphology 103: 1-13.

ONAI, T., ARAMAKI, T., INOMATA, H., HIRAI, T. and KURATANI, S. (2015a). Ancestral mesodermal reorganization and evolution of the vertebrate head. Zoological Lett 1: 29

ONAI, T., ARAMAKI, T., INOMATA, H., HIRAI, T. and KURATANI, S. (2015b). On the origin of vertebrate somites. Zoological Lett 1: 33.

ONAI, T., IRIE, N. and KURATANI, S. (2014). The evolutionary origin of the vertebrate body plan: the problem of head segmentation. Annu Rev Genomics Hum Genet 15: 443-459.

ONAI, T., LIN, H.C., SCHUBERT, M., KOOP, D., OSBORNE, P.W., ALVAREZ, S., ALVAREZ, R., HOLLAND, N.D. and HOLLAND, L.Z. (2009). Retinoic acid and Wnt/ beta-catenin have complementary roles in anterior/posterior patterning embryos of the basal chordate amphioxus. Dev Biol 332: 223-233.

ONAI, T., TAKAI, A., SETIAMARGA, D.H. and HOLLAND, L.Z. (2012). Essential role of Dkk3 for head formation by inhibiting Wnt/beta-catenin and Nodal/Vg1 signaling pathways in the basal chordate amphioxus. Evol Dev 14: 338-350.

ONAI, T., YU, J.K., BLITZ, I.L., CHO, K.W. and HOLLAND, L.Z. (2010). Opposing Nodal/Vg1 and BMP signals mediate axial patterning in embryos of the basal chordate amphioxus. Dev Biol 344: 377-389.

ONIMARU, K., SHOGUCHI, E., KURATANI, S. and TANAKA, M. (2011). Development and evolution of the lateral plate mesoderm: comparative analysis of amphioxus and lamprey with implications for the acquisition of paired fins. Dev Bio/359: 124-136.

OWEN, R. (1854). The principal forms of the skeleton and of the teeth. Blanchard and Lea, Philadelphia.

PANI, A.M., MULLARKEY, E.E., ARONOWICZ, J., ASSIMACOPOULOS, S., GROVE, E.A. and LOWE, C.J. (2012). Ancient deuterostome origins of vertebrate brain signalling centres. Nature 483: 289-294.

PARIS, M., ESCRIVA, H., SCHUBERT, M., BRUNET, F., BRTKO, J., CIESIELSKI, F., ROECKLIN, D., VIVAT-HANNAH, V., JAMIN, E.L., CRAVEDI, J.P. et al., (2008). Amphioxus postembryonic development reveals the homology of chordate metamorphosis. Curr Biol 18: 825-830.

PASCUAL-ANAYA, J., ALBUIXECH-CRESPO, B., SOMORJAI, I.M., CARMONA, R., OISI, Y., ALVAREZ, S., KURATANI, S., MUNOZ-CHAPULI, R. and GARCIAFERNANDEZ, J. (2013). The evolutionary origins of chordate hematopoiesis and vertebrate endothelia. Dev Biol 375: 182-192.

POURQUIE, O. (2011). Vertebrate segmentation: from cyclic gene networks to scoliosis. Cell 145: 650-663.

PUTNAM, N.H., BUTTS, T., FERRIER, D.E., FURLONG, R.F., HELLSTEN, U., KAWASHIMA, T., ROBINSON-RECHAVI, M., SHOGUCHI, E., TERRY, A., YU, 


\section{T. Onai et al.}

J.K. et al., (2008). The amphioxus genome and the evolution of the chordate karyotype. Nature 453: 1064-1071.

RAHR, H. (1982). Ultrastructure of gill bars of branchiostoma-lanceolatum with special reference to gill skeleton and blood-vessels (cephalochordata). Zoomorphology 99: 167-180.

RASMUSSEN, S.L., HOLLAND, L.Z., SCHUBERT, M., BEASTER-JONES, L. and HOLLAND, N.D. (2007). Amphioxus AmphiDelta: evolution of Delta protein structure, segmentation, and neurogenesis. Genesis 45: 113-122.

ROMER, A.S. (1972). The vertebrate as a dual animal--somatic and visceral. Evol. Biol. 6: 121-156.

RUPPERT, E.E. (1997). Cephalochordata (Acrania). In Microscopic Anatomy of Invertebrates, vol. 15, Hemichordata, Chaetognatha, and the Invertebrate Chordates (ed. Harrison FW, Ruppert EE),. New York: Wiley-Liss.349-504.

RYAN, J.F., PANG, K., SCHNITZLER, C.E., NGUYEN, A.D., MORELAND, R.T., SIMMONS, D.K., KOCH, B.J., FRANCIS, W.R., HAVLAK, P., SMITH, S.A. et al., (2013). The genome of the ctenophore Mnemiopsis leidyi and its implications for cell type evolution. Science 342: 1242592.

SCHUBERT, M., HOLLAND, L.Z., PANOPOULOU, G.D., LEHRACH, H. and HOLLAND, N.D. (2000). Characterization of amphioxus AmphiWnt8: insights into the evolution of patterning of the embryonic dorsoventral axis. Evol Dev 2: 85-92.

SCHUBERT, M., HOLLAND, L.Z., STOKES, M.D. and HOLLAND, N.D. (2001). Three amphioxus Wnt genes (AmphiWnt3, AmphiWnt5, and AmphiWnt6) associated with the tail bud: the evolution of somitogenesis in chordates. Dev Biol 240: 262-273.

SIMAKOV, O., KAWASHIMA, T., MARLETAZ, F., JENKINS, J., KOYANAGI, R., MITROS, T., HISATA, K., BREDESON, J., SHOGUCHI, E., GYOJA, F. et al., (2015). Hemichordate genomes and deuterostome origins. Nature 527: 459-465.

SOUKUP, V., YONG, L.W., LU, T.M., HUANG, S.W., KOZMIK, Z. and YU, J.K. (2015). The Nodal signaling pathway controls left-right asymmetric development in amphioxus. Evodevo 6: 5.

STACH, T. (1996). On the preoral pit of the larval amphioxus (Branchiostoma lanceolatum). Annales des Sciences naturelles, Zoologie, Paris. 17: 129-134.

STOLFI, A., RYAN, K., MEINERTZHAGEN, I.A. and CHRISTIAEN, L. (2015). Migratory neuronal progenitors arise from the neural plate borders in tunicates. Nature 527: $371-374$
VAN WIJHE, J.W. (1882). Über die Mesodermsegmente und die Entwicklung der Nerven des Selachierkopfes.. Groningen: Ver Akad Wiss Amsterdam, pp1-50.

VAN WIJHE, J.W. (1902). Beiträge zur Anatomie de Kopfregion des Amphioxus lanceolatus. Petrus Camper (Ned. Bijdr. Anat.) 1: 109-194 + XVIII-XI.

VAN WIJHE, J.W. (1914). Studien über Amphioxus. I. Mund und Darmkanal während der Metamorphose. Verh. K. Akad. Wet. Amsterdam, Section 218: 1-84 + pl. I-V.

VENKATESH, T.V., HOLLAND, N.D., HOLLAND, L.Z., SU, M.T. and BODMER, R. (1999). Sequence and developmental expression of amphioxus AmphiNk2-1 insights into the evolutionary origin of the vertebrate thyroid gland and forebrain. Dev. Genes Evol. 209: 254-259.

WEISS, F.E. (1890). Excretory tubules in Amphioxus lanceolatus. QJMS31: 489-497

WILLEY, A. (1891). The later larval development of Amphioxus. Quart. J. Microscop. Sci. 32: 183-234.

YASUI, K., KAJI, T., MOROV, A.R. and YONEMURA, S. (2014). Development of oral and branchial muscles in lancelet larvae of Branchiostoma japonicum. $J$ Morphol 275: 465-477.

YASUI, K., ZHANG, S., UEMURA, M. and SAIGA, H. (2000). Left-right asymmetric expression of BbPtx, a Ptx-related gene, in a lancelet species and the developmental left-sidedness in deuterostomes. Development 127: 187-195.

YU, J.K., HOLLAND, L.Z. and HOLLAND, N.D. (2002a). An amphioxus nodal gene (AmphiNodal) with early symmetrical expression in the organizer and mesoderm and later asymmetrical expression associated with left-right axis formation. Evol Dev 4: 418-425

YU, J.K., HOLLAND, L.Z., JAMRICH, M., BLITZ, I.L. and HOLLAN, N.D. (2002b) AmphiFoxE4, an amphioxus winged helix/forkhead gene encoding a protein closely related to vertebrate thyroid transcription factor-2: expression during pharyngea development. Evol Dev 4: 9-15.

YU, J.K., SATOU, Y., HOLLAND, N.D., SHIN, I.T., KOHARA, Y., SATOH, N., BRONNERFRASER, M. and HOLLAND, L.Z. (2007). Axial patterning in cephalochordates and the evolution of the organizer. Nature 445: 613-617.

ZHANG, S.-C., HOLLAND, N.D. and HOLLAND, L.Z. (1997). Topographic changes in nascent and early mesoderm in amphioxus embryos studied by Dil labeling and by in situ hybridization for a Brachyury gene. Dev Genes Evol. 206: 532-535. 


\section{Further Related Reading, published previously in the Int. J. Dev. Biol.}

From the American to the European amphioxus: towards experimental Evo-Devo at the origin of chordates Jordi Garcia-Fernàndez, Senda Jiménez-Delgado, Juan Pascual-Anaya, Ignacio Maeso, Manuel Irimia, Carolina Minguillón, Èlia BenitoGutiérrez, Josep Gardenyes, Stéphanie Bertrand and Salvatore D'Aniello Int. J. Dev. Biol. (2009) 53: 1359-1366 https://doi.org/10.1387/ijdb.072436jg

Evolution of CUT class homeobox genes: insights from the genome of the amphioxus, Branchiostoma floridae Naohito Takatori and Hidetoshi Saiga Int. J. Dev. Biol. (2008) 52: 969-977 https://doi.org/10.1387/ijdb.072541nt

Peter Holland, homeobox genes and the developmental basis of animal diversity Sebastian M. Shimeld Int. J. Dev. Biol. (2008) 52: 3-7 https://doi.org/10.1387/ijdb.072394ss

Developmental expression of the High Mobility Group B gene in the amphioxus, Branchiostoma belcheri tsingtauense

Xiangwei Huang, Lifeng Wang and Hongwei Zhang

Int. J. Dev. Biol. (2005) 49: 49-46

http://www.intjdevbiol.com/web/paper/041915xh

Cell morphology in amphioxus nerve cord may reflect the time course of cell differentiation T C Lacalli

Int. J. Dev. Biol. (2000) 44: 903-906

http://www.intjdevbiol.com/web/paper/11206331

Embryonic development of heads, skeletons and amphioxus: Edwin S. Goodrich revisited P W Holland

Int. J. Dev. Biol. (2000) 44: 29-34

http://www.intjdevbiol.com/web/paper/10761843

Amphioxus Hox genes: insights into evolution and development

$\mathrm{J}$ Garcia-Fernàndez and $\mathrm{P}$ W Holland

Int. J. Dev. Biol. (1996) 40: S71-S72

http://www.intjdevbiol.com/web/paper/9087701

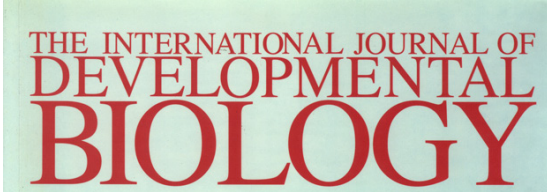

5 yr ISI Impact Factor $(2013)=2.879$
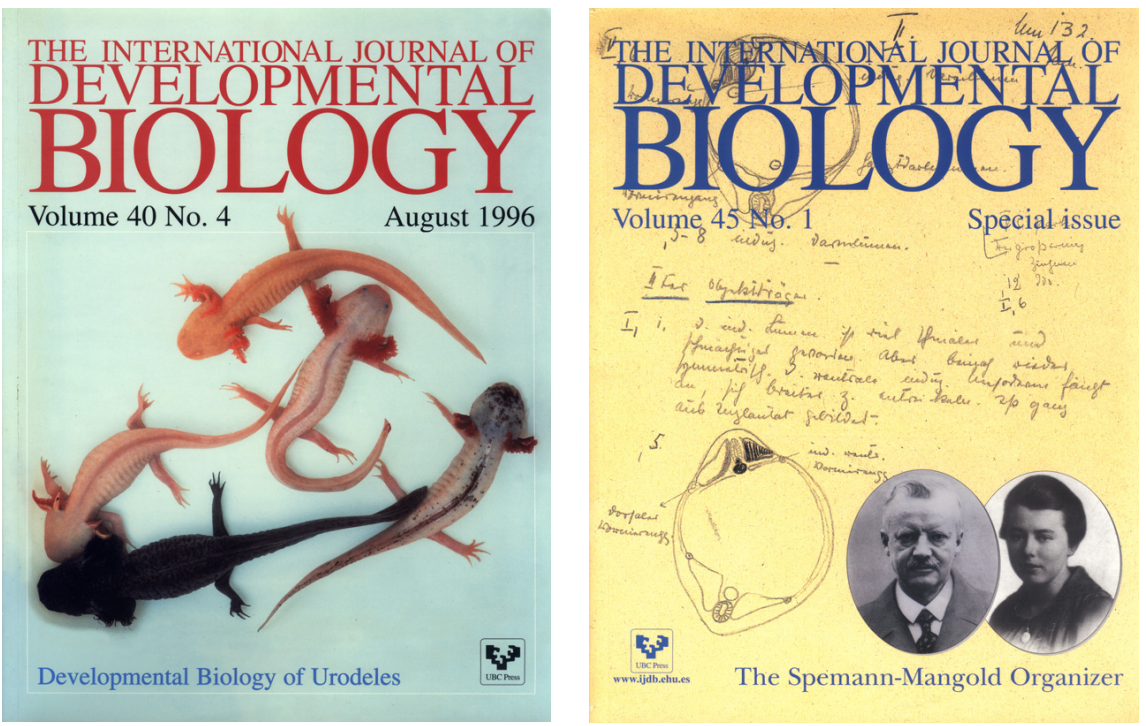

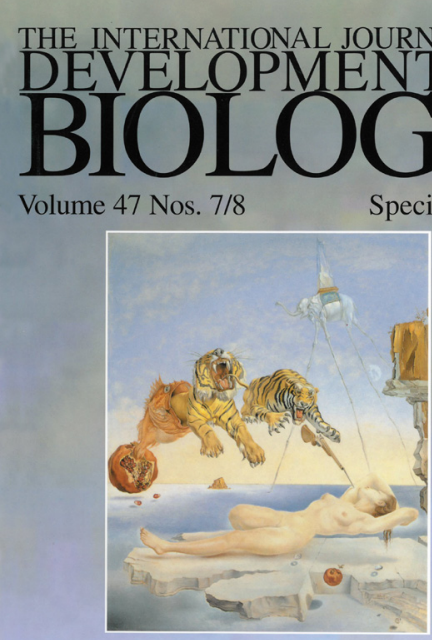

Evolution \& Development
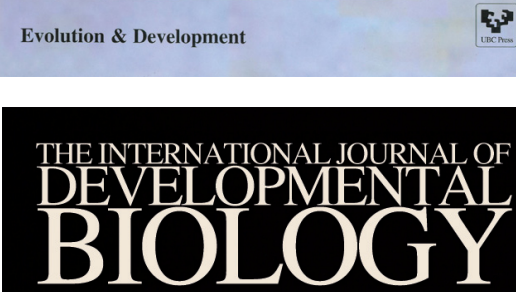

Volume 61 Nos. 10/11/12 Special Issue

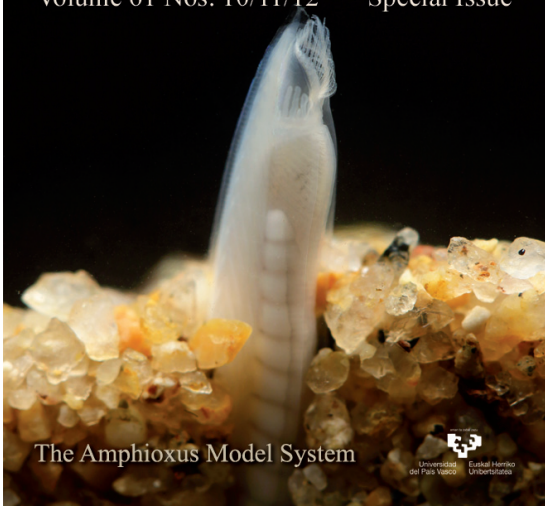

